\title{
LUNG METASTASES OF LOW GRADE PHYLLODES TUMOR OF THE PROSTATE: HISTOPATHOLOGIC CONFIRMATION
}

\author{
David Parada, Gustavo Ugas', Karla Peña, Luis Caricote' and Nelson Mujica'.
}

Servicio de Anatomía Patológica. Hospital Vargas. Caracas. Venezuela.

Urólogos'. Centro Médico El Valle. Isla de Margarita. Venezuela.

\begin{abstract}
Summary.- OBJECTIVE: Phyllodes tumor of the prostate is a rare neoplasm. We report the clinical, histopatho-logical, and immunohistochemical features of a low grade phyllodes tumor of the prostate with lung metastases.

METHODS: A 68-year-old man presented acute urinary obstruction. Suprapubic prostatectomy was performed, and one month later he developed acute urinary obstruction, shortness of breath and cough.

RESULTS: Microscopically, the prostatic tumor showed elongated ducts and cellular stroma. Lung biopsy was composed of stromal cells with enlarged, hyperchromatic nuclei.
\end{abstract}

CONCLUSION: This case represents a typical low grade prostatic phyllodes tumor to lung. Grading of these neoplasm is not always of value to predict patient prognosis.
Keywords: Phyllodes tumor. Prostate. Malignant.

Metastases. Lung.

Resumen.- OBJETIVO: El tumor phyllodes de la prostata es una rara neoplasia. Nosotros reportamos los hallazgos clínicos, histopatológicos e inmunohistoquímicos de un tumor phyllodes de la prostata con metastasis pulmonar.

MÉTODOS: Un paciente de 68 años sufrió de obstrucción urinaria aguda. Se practicó una prostatectomía suprapúbica, un mes después desarrollo obstrucción urinaria, dificultad respiratoria y tos.

RESULTADOS: Microscópicamente, el tumor prostático mostró ductos elongados y estroma celular. La biopsia pulmonar estaba compueta de células estromales con núcleos hipercromáticos, alargados.

CONCLUSIÓN: Este caso representa un típico phyllodes prostático de bajo grado metastizando al pulmón. La gradación de stas neoplasias no es siempre de valor para predecir el pronóstico.

Palabras clave: Tumor Phyllodes. Próstata. Maligno. Metástasis. Pulmón.

\section{INTRODUCTION}

Servicio de Patología Hospital Vargas San Francisquito a Monte Carmelo Esquina El Recodo, San José Apdo. 1010 Caracas. (Venezuela). parada@cantv.net

Phyllodes tumor of the prostate is an extremely rare neoplasm that resembles the well-known phyllodes tumor of the breast, with a distinctive biphasic pattern of hyperplastic epithelium lined cysts, leaf-like intraluminal projections, compressed and elongated slit-like epithelial lined spaces, and variable cellular spindle cell stroma with cytological atypia (1-3). It has 
been reported as liable to early recurrence, with an occasional metastatic potential $(1,3,4)$.

In this report we describe a 68-year-old man who developed low grade phyllodes tumor of the prostate that metastasized to the lung. To the best of our knowledge this is the second case in which such an evolution is documented. We also briefly review the literature.

\section{CASE REPORT}

A 68-year-old man complained of acute urinary obstruction. He had suffered from a diminished urinary
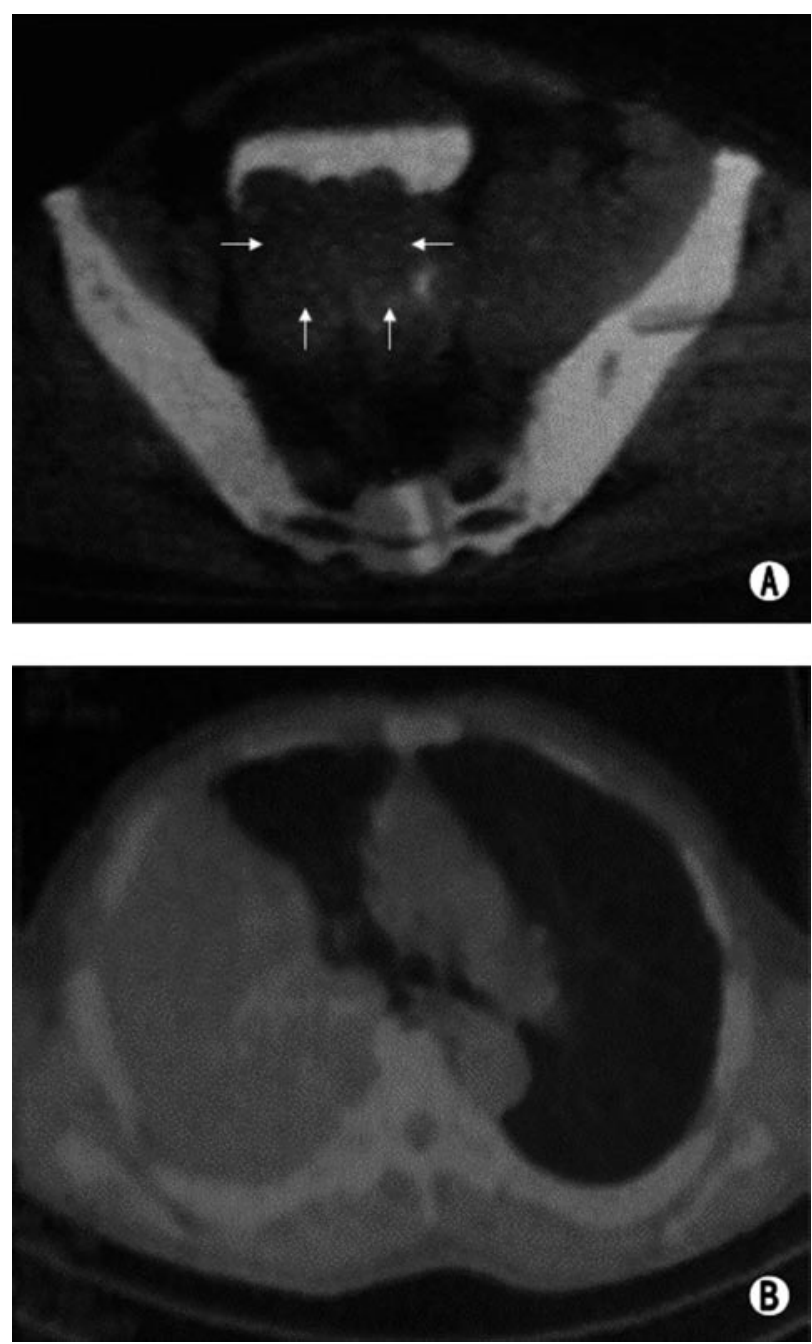

FIGURE 1. A, Abdominal Computerized Tomography.

The tumor (White arrows) is located centrally and arising into the urinary bladder (after first resection).

B, Thoracic Computerized Tomography.

A right posterior tumor is observed. This lesion was interpreted as metastatic. stream and frequency during 6 months. Digital rectal examination revealed a benign feeling prostate. The rest of the physical examination was unremarkable. Prostate specific antigen (PSA) level was $1.1 \mathrm{ng} / \mathrm{ml}$ (normal: < $4.0 \mathrm{ng} / \mathrm{ml}$ ). An abdominal ultrasonography confirmed prostatic enlargement. Cystoscopy revealed a normal urethra. The bladder base was elevated at the bladder neck but the mucosa was normal. Clinical diagnosis was benign prostatic hyperplasia (BPH) grade III. A suprapubic prostatectomy was performed, with a histological diagnosis of benign prostatic hyperplasia One month later the patient had a new episode of acute urinary obstruction. An abdomino-pelvic CT showed a $12 \mathrm{~cm}$ irregular tumor, protruding into the bladder (Figure 1A) and bilateral ureterohydronephrosis. A TURP gave a histological diagnosis of myofibroblastic inflammatory tumor. Additionally, the patient developed shortness of breath and cough. A chest roentgenogram and a $C T$ revealed a peripheral lesion at the right lung (Figure 1B). A histological analysis done through an open lung biopsy was consistent with an inflammatory process and atypical mesenchimal proliferation. After the histological conclusion, the patient received chemotherapy treatment. The patient died due to cardiac arrest.

\section{PATHOLOGIC FINDINGS}

Paraffin-embedded tissue and histological preparations were available (courtesy of Cristina Pastrán, MD, of Porlamar, Nva. Esparta, Venezuela). Sections of paraffin-embedded tissue were stained for conventional histological study with haematoxylineosin. Immunohistochemical studies were performed using the labeled $\angle S A B \otimes$ method (DAKO®, Carpintería, USA). Monoclonal/polyclonal antibodies were used at dilutions suggested by the manufacturer (between 1:50 and 1:200). Antibodies were directed against smooth muscle actin, CD34, CD 117, S-100 protein, vimentin, estrogen and progesterone receptors, myoglobin D1, broad-spectrum cytokeratin $A E 1 / A E 3$, high molecular weight keratin (34ßE12), epithelia membrane antigen (EMA), prostatic specific antigen (PSA), p53 protein and $\mathrm{Ki}-67$ proliferating nuclear antigen. Appropriate positive controls were prepared for each. Sections processed without primary antibodies were employed as negative controls. Scoring was based on the percentage of positive tumor cells.

Microscopic examination of the prostatic biopsy showed complete replacement by a biphasic tumor. The tumor showed elongated ducts and cellular stroma, resembling a phyllodes tumor of the breast ( Figure 2 A,B). The epithelial cells lining the ducts were 

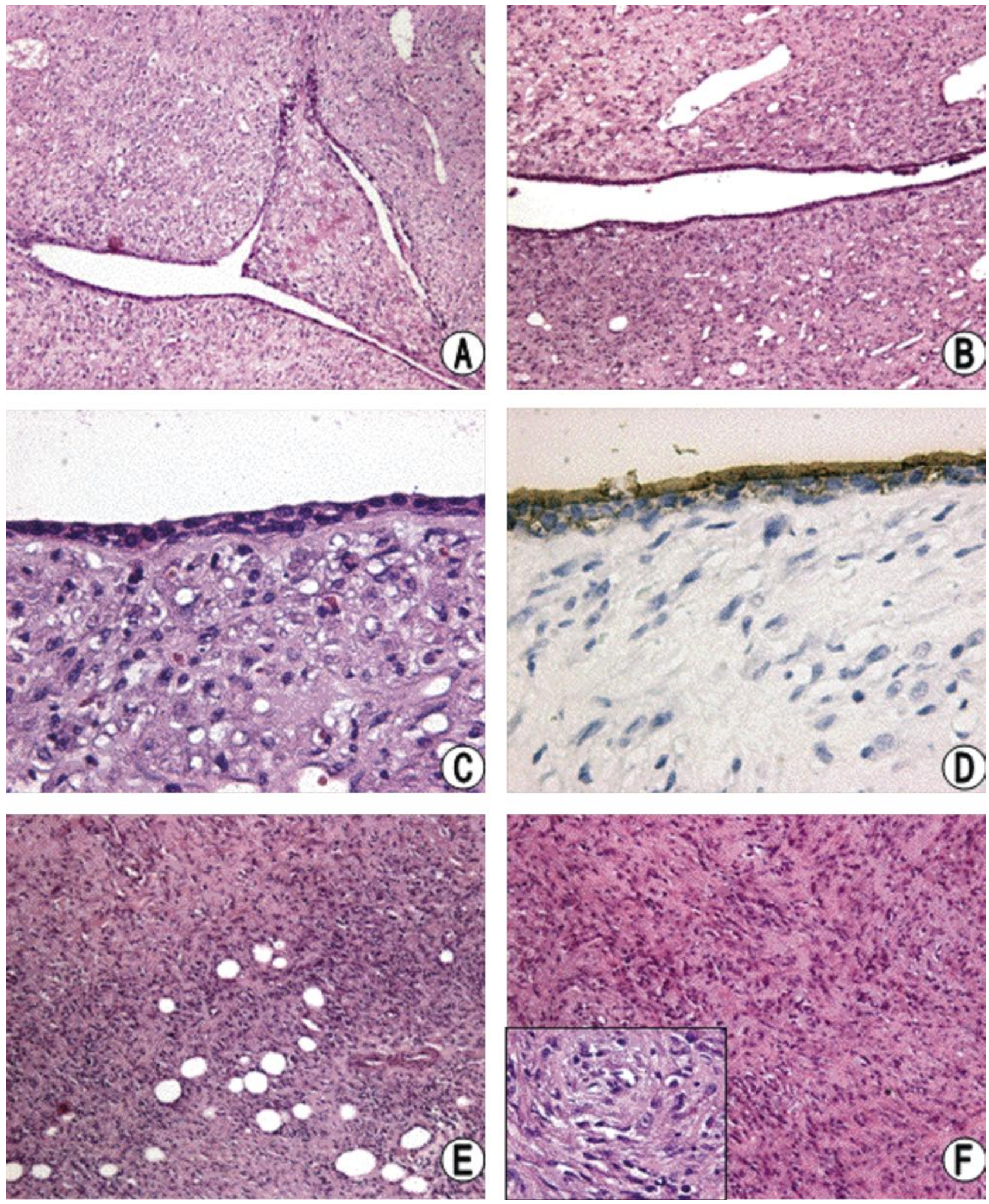

FIGURE 2. Microscopic findings. A, Cleftlike spaces lined by epithelial cells. (H-E 40x). B, Elongated ducts and cellular stroma, resembling phyllodes tumor of the breast. Neoplastic cells showing no clear boundary between the tumor and epithelial cells (H-E 100x, detaill. C, Cuboidal, epithelial cell lining of the ducts with oval nuclei and inconspicuous nucleoli (H-E 400x). D. Epithelial cells showing strong reactivity to prostatic specific antigen (DAB, 400x). E, Metastatic lung biopsy showing stromal neoplasia (H-E 40x). F, Stromal cells with enlarged, hyperchromatic nuclei intermixed with bland, spindled nuclei. These cells had moderate amount of eosinophilic cytoplasm (H-E 
cuboidal to columnar with oval nuclei and inconspicuous nucleoli (Figure 2C). No atypia was observed. The stroma cells were variable with dense cellular areas with hyperchromatic ovoid cells that condensed the glands forming loose and myxomatous areas (Figure $2 \mathrm{~A}, \mathrm{~B}, \mathrm{C})$. Few mitosis (1-2/ $10 \mathrm{HPF}(400 \mathrm{X})$ ) were seen. Perineural, lymphatic or vascular invasion was not found.

An immunohistochemical study of stromal cells showed focal positivity for CD34 and smooth muscle actin. Epithelial cells were positive to PSA and EMA (Figure 2D). Stromal cells failed to stain for estrogen receptor, progesterone receptor, CD 117 , desmin, myoglobin $\mathrm{Dl}, \mathrm{S} 100$ protein and cytokeratin AE 1/AE3. p53 immunostaining was negative in epithelial and stromal components. Immunoreactivity to $\mathrm{Ki}-67$ (proliferanting nuclear antigen) showed about $45 \%$ of stromal tumor cells with nuclear positivity. According to Bostwick's et al. (1) grading, the tumor was interpreted as low grade phyllodes tumor of the prostate.

Histological material obtained from the lung biopsy was also examined. The tumor was exclusively formed by stromal cells with enlarged, hyperchromatic nuclei intermixed with bland, spindled nuclei (Figure $2 \mathrm{E}, \mathrm{F})$. Nucleoli were not visible and mitoses were not found. These cells had a moderate amount of eosinophilic cytoplasm and in some areas they resembled smooth muscle cells (Figure $2 \mathrm{E}, \mathrm{F}$ ). Immunohistochemical results were similar to the prostatic tumor, with focal CD34 and smooth muscle actin reactivity. Normal pulmonary tissue was not seen. The final diagnosis was metastatic low grade sarcoma, consistent with metastatic prostatic phyllodes tumor.

\section{DISCUSSION}

Phyllodes tumor of the prostate is a rare lesion, analogous to epithelial-stromal lesions of the breast, of unknown histogenesis (1). Like their breast homonymous, phyllodes tumors of the prostate vary in their histological appearance and clinical behavior. Patients typically consult due to urinary obstruction, hematuria and dysuria. These symptoms were referred by our patient, with progression to acute urinary obstruction. Additionally, the serum PSA level was normal.

Although most reported prostate cases show a benign clinical course, some have been reported to be malignant $(1,5-7)$. Five histological features have been proposed for correlating the clinical outcome: stromal cellurarity, cytological atypia, mitotic figures (in 10 high power field), stromal/epithelia ratio, and necrosis (1). Our case was interpreted as low grade, considering its low stromal cellularity, mild cytologic atypia, less than 2 mitosis in $10 \mathrm{HPF}$, mild stromal/ epithelial ratio, and absence of necrosis. Our findings are consistent with those showing low grade tumors with local recurrence and presence of metastases. Additionally, phyllodes tumor of the prostate should be considered a neoplasm rather than atypical hyperplasia due to early recurrences and metastatic spread.

The histology of the metastatic deposits has not been well documented. There is only one report of a fine needle aspiration biopsy of a prostatic phyllodes tumor that presented a bone metastasis that showed malignant spindle cells, consistent with leyomiosarcoma (8).

In our case it was possible to compare the histological findings in a primary prostatic lesion with a lung metastasis. In this last one the tumor was exclusively composed by mesenchimal cells with similar characteristics to those observed in the prostatic lesion (mild stromal cellularity and cytologic atypia, low mitotic index (less than 2 mitosis/10 HPF, and no necrosis). To the best of our knowledge this is the first case in the English literature with histological confirmation of a prostatic phyllodes tumor with lung metastases, showing that the stromal component was similar in both cases. Sarcoma frequently emerges from primary or metastatic lesions. In our patient, there was no transformation to high grade sarcoma. On the other hand, similar stromal findings were observed and this probably suggests that a change from a low grade to high grade sarcoma is not necessary to produce metastatic disease. Because there are so few of these tumors, it has been suggested that all cases should be reported in the literature, to help to evaluate the relationship between histological findings and clinical behavior.

\section{CONCLUSION}

Our case represents a typical phyllodes tumor of the prostate with lung metastases. These tumors should be considered as a neoplasm rather than an atypical hyperplasia due to recurrences, as well as the potential for extraprostatic and metastatic spread. The stromal component has a metastatic potential and grading is not always of value for predicting patient outcome. 


\section{REFERENCES AND RECOMENDED READINGS (*of special interest, ${ }^{* *}$ of outstanding interest)}

**1. BOSTWICK, D.; HOSSAIN, D.; QIAN J. et al.: "Phyllodes tumor of the prostate: Long-term follow-up study of 23 cases." J. Urol., 172: 894, 2004.

*2. SHIRAISHI, K.; MORI, J.; EGUCHI, S. et al.: "Phyllodes tumor of the prostate: Recurrent obstructive symptom and stromal proliferative activity," Int. J. Urol., 11: 801, 2004.

3. SCHAPMANS, S.; VAN LEUVEN, L.; CORTVRIEND, J. et al.: "Phyllodes tumor of the prostate. A case report and review of the literature." Eur. Urol., 38: 649, 2000.

**4. HERAWI, M.; EPSTEIN, J.: "Specialized stromal tumors of the prostate: A clinicopathologic study of 50 cases,” Am. J. Surg. Pathol., 30: 694, 2006.

5. KIM, H.; LEE, J.; NAM, J. et al.: "Malignant phyllodes tumor of the prostate." Pathol. Int., 49: 1105, 1999.

6. WATANABE, M.; YAMADA, Y.; KATO, H. et al.: "Malignant phyllodes tumor of the prostate: retrospective review of specimens obtained by sequential transurethral resection”. Pathol. Int., 52: 777, 2002.

7. YAMAMOTO, S.; ITO, T.; MIKI M. et al.: "Malignant phyllodes tumor of the prostate." Int. J. Urol., 7: 378, 2000.

*8. YUM, M.; MILLER, J.; AGRAWAL, J.: "Leiomyosarcoma arising in atypical fibromuscular hyperplasia (phyllodes tumor) of the prostate with distant metastasis." Cancer., 68: 910,1990. 